University of Nebraska - Lincoln

DigitalCommons@University of Nebraska - Lincoln

USDA National Wildlife Research Center - Staff Publications
U.S. Department of Agriculture: Animal and Plant Health Inspection Service

May 2005

\title{
Caffeine for reducing bird damage to newly seeded rice
}

\author{
Michael L. Avery \\ USDA/APHIS/WS National Wildlife Research Center, michael.I.avery@aphis.usda.gov \\ Scott J. Werner \\ USDA-APHIS-Wildlife Services, scott.j.werner@aphis.usda.gov \\ John L. Cummings \\ USDA-APHIS-Wildlife Services \\ John S. Humphrey \\ USDA/APHIS/WS National Wildlife Research Center, John.S.Humphrey@aphis.usda.gov \\ Michael P. Milleson \\ USDA/APHIS/WS National Wildlife Research Center
}

See next page for additional authors

Follow this and additional works at: https://digitalcommons.unl.edu/icwdm_usdanwrc

Part of the Environmental Sciences Commons

Avery, Michael L.; Werner, Scott J.; Cummings, John L.; Humphrey, John S.; Milleson, Michael P.; Carlson, James C.; Primus, Thomas M.; and Goodall, Margaret J., "Caffeine for reducing bird damage to newly seeded rice" (2005). USDA National Wildlife Research Center - Staff Publications. 5.

https://digitalcommons.unl.edu/icwdm_usdanwrc/5

This Article is brought to you for free and open access by the U.S. Department of Agriculture: Animal and Plant Health Inspection Service at DigitalCommons@University of Nebraska - Lincoln. It has been accepted for inclusion in USDA National Wildlife Research Center - Staff Publications by an authorized administrator of DigitalCommons@University of Nebraska - Lincoln. 


\section{Authors}

Michael L. Avery, Scott J. Werner, John L. Cummings, John S. Humphrey, Michael P. Milleson, James C. Carlson, Thomas M. Primus, and Margaret J. Goodall 


\title{
Caffeine for reducing bird damage to newly seeded rice
}

\author{
Michael L. Avery ${ }^{\mathrm{a}, *}$, Scott J. Werner ${ }^{\mathrm{b}}$, John L. Cummings ${ }^{\mathrm{b}}$, John S. Humphrey ${ }^{\mathrm{a}}$, \\ Michael P. Milleson $^{a}$, James C. Carlson ${ }^{b}$, Thomas M. Primus ${ }^{b}$, Margaret J. Goodall ${ }^{b}$ \\ ${ }^{a}$ United States Department of Agriculture, Animal and Plant Health Inspection Service, Wildife Services, National Wildife Research Center, \\ 2820 East University Avenue, Gainesville, FL 32641, USA \\ ${ }^{\mathrm{b}}$ United States Department of Agriculture, Animal and Plant Health Inspection Service, Wildife Services, National Wildlife Research Center, \\ 4101 LaPorte Avenue, Fort Collins, CO 80521, USA
}

Received 30 July 2004; received in revised form 4 November 2004; accepted 8 November 2004

\begin{abstract}
The economic impact of blackbirds can be severe to rice producers in the United States. One approach to managing this damage is the application of bird-deterrent chemical to the crop. Previous pilot trials suggested that caffeine offered potential as a safe, economical bird repellent. In this study, cage feeding trials with female red-winged blackbirds and male brown-headed cowbirds confirmed that a treatment rate of $2500 \mathrm{ppm}$ caffeine on rice seed reduced consumption as much as $76 \%$. Trials with mixed species blackbird flocks in a 0.2 -ha flight pen resulted in just 4\% loss of caffeine-treated rice compared to $43 \%$ loss of untreated rice. Field trials of a 10,000 ppm caffeine treatment in Louisiana revealed $>90 \%$ of caffeine-treated rice seed remained unconsumed on days 2 and 3 of the study whereas blackbirds consumed $>80 \%$ of the untreated seed. As a rice seed treatment to deter blackbirds, caffeine appears to be effective, economical and environmentally safe, although additional aquatic toxicity testing is desirable. Improvements in formulation will be needed to make the compound practical for general agricultural spray applications and to extend the adherence of caffeine to rice seeds in field conditions.
\end{abstract}

Published by Elsevier Ltd.

Keywords: Agelaius phoeniceus; Bird repellent; Blackbird; Caffeine; Crop damage; Louisiana; Molothrus ater; Rice; Seed treatment

\section{Introduction}

In the United States, several species of blackbird, particularly red-winged blackbirds (Agelaius phoeniceus), grackles (Quiscalus sp.), and brown-headed cowbirds (Molothrus ater) inflict estimated damage worth $\$ 11.5$ million to newly planted and ripening rice (Besser, 1985). Damage is not uniformly distributed, but is localized and generally proportional to the size of nearby blackbird roosts. In Texas, losses in newly seeded rice are estimated at $\$ 4.2$ million (Decker et al., 1990). In Louisiana, locally severe blackbird damage to

\footnotetext{
${ }^{*}$ Corresponding author. Tel.: + 13523752229 ; fax: +13523775559 .

E-mail address: michael.1.avery@aphis.usda.gov (M.L. Avery).
}

newly planted rice sometimes requires the crop be replanted (Wilson et al., 1989).

Application of a bird-deterrent chemical is one means for growers to reduce losses to birds. Despite extensive research and testing of many promising compounds, however, commercial development and regulatory agency approval of a safe, effective bird repellent remain elusive (Avery et al., 1995, 1998; Avery and Cummings, 2003).

We became interested in the possible bird-repellent uses of caffeine because previous screening trials with male red-winged blackbirds revealed it to have relatively low toxicity $\left(\mathrm{LD}_{50}=316 \mathrm{mg} \mathrm{kg}^{-1}\right)$ with a relatively high repellency rating (Schafer et al., 1983). Initial feeding trials with individually caged male red-winged blackbirds determined that caffeine applied at a rate of 
$2500 \mathrm{ppm}$ to rice seed reduced consumption of the seed by $76 \%$ (Avery and Cummings, 2003).

Caffeine is a powerful central nervous system stimulant that is widely distributed in nature and widely consumed by humans. Worldwide, it is estimated that humans ingest 120,000 tons of caffeine each year, principally through consumption of coffee and tea (Weinberg and Bealer, 2001). Other common sources of caffeine include soft drinks, chocolate, and various prescription and nonprescription medicines.

Caffeine is a purine alkaloid and is known chemically as 1,3,7-trimethylxanthine. It is moderately soluble in water at body temperature, and freely soluble in water $>80^{\circ} \mathrm{C}$ (Windholz, 1983). Because caffeine is watersoluble, it readily passes through all cell membranes in the body. Thus, following ingestion, caffeine is absorbed rapidly from the stomach and intestines into the blood stream and then dispersed to all body organs, including the brain. Caffeine is not stored or sequestered within the body, and within $12 \mathrm{~h}$ of ingestion, $90 \%$ of the caffeine consumed has been metabolized and excreted (Weinberg and Bealer, 2001).

Dozens of plants contain caffeine, particularly those which produce coffee, tea, and cacao. In these plants, caffeine has antibacterial and antifungal properties. It also causes sterility in some insects. The insecticidal properties of caffeine prompted suggestions that the compound be developed for pest management purposes (Nathanson, 1984), including as a repellent or toxicant for slugs and snails (Hollingsworth et al., 2002).

In this study, we extend our earlier findings in cage feeding trials to female red-winged blackbirds and male brown-headed cowbirds, and we report on mixedspecies blackbird feeding trials conducted with captive birds within a 0.2-ha flight pen and with free-flying birds on field plots in Louisiana, USA.

\section{Methods}

\subsection{Trials with captive birds}

\subsubsection{Seed treatment}

We prepared rice seed in 1-kg batches. We dissolved the appropriate amount of caffeine (Sigma Chemicals, St. Louis, MO, USA) in $60 \mathrm{ml}$ of warm $\left(60-65^{\circ} \mathrm{C}\right)$ distilled water with $0.5 \mathrm{ml}$ of a commercial agricultural spreader/binder (Latron CS-7, Rohm and Haas Company, Philadelphia, PA, USA). We slowly added this mixture to $1 \mathrm{~kg}$ of rice as it turned in a rotating mixer. Mixing continued for $5 \mathrm{~min}$ until the rice seed flowed freely in the mixer. We then airdried and stored the treated seed in an air-conditioned laboratory.

\subsubsection{Experimental subjects}

For this study, we used 36 female red-winged blackbirds, 36 male brown-headed cowbirds, and 16 male red-winged blackbirds. We trapped birds locally in Alachua County, FL, USA and held them 1-3 months prior to testing. We housed birds in group cages $\left(1.2 \times 1.2 \times 1.6 \mathrm{~m}^{3}\right)$ in a roofed outdoor aviary and provided free access to water, grit and maintenance food (quail starter, Hillandale Farms, Lake Butler, FL, USA).

\subsubsection{Individual cage trials}

We conducted feeding trials in a roofed outdoor aviary, where test cages $\left(45 \times 45 \times 45 \mathrm{~cm}^{3}\right)$ were visually isolated and equipped with trigger-cup waterers. We presented food in clear plastic feed cups $(8.2 \mathrm{~cm}$ diameter, $3.8 \mathrm{~cm}$ high) with a circular opening $(3.1 \mathrm{~cm}$ diameter) in the top. Four days before the start of the trial, we removed birds from their holding cages, weighed them, and randomly assigned each to a test cage. Test groups ( 3 treatment and 1 untreated control group) of 5 birds each were formed by randomly assigning birds to receive either untreated rice or rice treated with caffeine at 1000,1500 , or $2500 \mathrm{ppm}$. During the 4-day acclimation period, we provided birds with a mixture of rice seed and commercial quail starter diet.

Following acclimation, there was a 4-day pretreatment period, a 2-day break, and a 4-day treatment period. During pretreatment, each bird's test cup held $20 \mathrm{~g}$ of untreated rice seed. During the 2-day weekend break, quail starter was provided. In the treatment phase, birds in the treatment cages received treated rice and the control group received untreated rice. During the treatment period, we videotaped one bird given treated seed to observe immediate and subsequent behavioral responses to the treatment.

During the pretreatment and treatment periods, we removed quail starter maintenance food at 07:00, and $1 \mathrm{~h}$ later placed the test food cups in the cages. Aluminum trays suspended from test cages under each cup caught spillage. The spillage information was used to estimate the proportion of rice seed removed from the cups that was actually eaten. Cups containing test food not exposed to birds were put in vacant cages to determine mass changes due to moisture. After $3 \mathrm{~h}$, test food was removed and the birds' maintenance food again provided. Contents of test food cups were weighed and consumption determined by subtraction after appropriate adjustments for spillage and moisture gain. After the final treatment day, test birds were reweighed, banded, and released. The entire test sequence was completed with female red-winged blackbirds and male brown-headed cowbirds.

Consumption data for blackbirds and cowbirds were analyzed in separate 2-way analyses of variance with caffeine level as the independent factor and repeated 
measures across days. There were five replications $(=5$ birds) per treatment level.

\subsubsection{Flight pen trial}

Within a 0.2 -ha flight pen, we tilled and smoothed two plots $\left(20 \times 25 \mathrm{~m}^{2}\right)$. We then created eight $3 \times 15-\mathrm{m}^{2}$ strips within the tilled area and randomly designated four strips to receive caffeine-treated $(2500 \mathrm{ppm})$ rice and four to receive untreated rice. Test strips were separated by $2-\mathrm{m}$ buffers. We removed 4 male and 4 female red-winged blackbirds and 3 male brown-headed cowbirds from their communal holding cages and placed them in a group pen $\left(9.3 \times 3.1 \times 1.6 \mathrm{~m}^{3}\right)$ within the flight pen to acclimate for $24 \mathrm{~h}$. On the morning of the first test day, we scattered by hand $500 \mathrm{~g}$ of treated rice seed over one randomly determined treatment strip and $500 \mathrm{~g}$ of untreated rice on one randomly determined untreated test strip. Within each test strip, we randomly located 10 sampling quadrats $\left(0.19 \mathrm{~m}^{2}\right)$ and set the initial count within each sampling quadrat to 48 rice seeds, a number readily counted without error yet sufficiently high not to be depleted during the trial. We then released birds into the pen. After $72 \mathrm{~h}$, we recorded the seeds remaining on each sampling quadrat, released the test birds, and prepared the test plots for the next set of birds. We conducted four replications, each with a new group of test birds. We evaluated the null hypothesis of no difference in seed loss between treated and untreated test strips with a paired $t$-test.

\subsection{Field evaluation}

In February 2004, we established five field sites (0.6-0.8 ha site $\left.{ }^{-1}\right)$ near traditional blackbird roosting areas and/or under major flightlines emanating from those roosts in Vermilion Parish and Cameron Parish, Louisiana, USA. All sites had moderate numbers of blackbirds feeding $\left(\sim 200-400\right.$ birds ha $\left.^{-1}\right)$ throughout the study. Each test site was plowed, leveled, and prebaited with untreated rice for 3-5 days to establish blackbird feeding activity. Rice was applied with ground equipment at a rate of $10 \mathrm{~kg} \mathrm{lane^{-1 }}$ on four $10 \times 100-\mathrm{m}^{2}$ lanes (approximately 350 seeds $\mathrm{m}^{-2}$ ), with a $25-\mathrm{m}$ buffer between lanes.

We treated $20 \mathrm{~kg}$ of rice with $10,000 \mathrm{ppm}$ caffeine (w/w) and 1000 ppm Transfilm ${ }^{\circledR}$ (PBI/Gordon, Kansas City, Missouri, USA) for each site. Rice was prepared by placing the seed in a mixer and spraying the rice at the appropriate application rate for $4 \mathrm{~min}$ as the mixer rotated. We poured treated rice into a container and stored for less than $24 \mathrm{~h}$ before broadcasting it onto the test sites. Following the pretreatment period, we randomly selected two lanes in each field for treatment. The two remaining lanes received untreated rice at the same rate as the treatment lanes. We re-applied rice when visual inspection revealed that $<25 \%$ of the treated or untreated rice that was applied the preceding day remained on the bait lane.

We observed blackbirds foraging at each site between 07:00 and 11:00 daily for 3 days. After estimating initial numbers of blackbirds on each of the four lanes at the test site, we recorded for $30 \mathrm{~min}$ the number of birds entering and leaving each lane. We randomized the starting time and location for bird observations throughout the study.

We established 10 sampling plots $\left(30 \times 30 \mathrm{~cm}^{2}\right)$ along the center-line of each lane at each test site to estimate daily consumption of rice by blackbirds. Plots were placed systematically at 9-m intervals beginning with a random starting point between 1 and $9 \mathrm{~m}$. We set each plot initially at 25 rice seeds to approximate the surrounding density of broadcast rice seed. On the next 3 mornings, we counted seeds on each sampling plot and reset each plot to 25 seeds. We applied SAS (1999) to conduct ANOVAs associated with the randomized block (field) design for blackbird abundance and for rice consumption at the test sites. We used the treatment-by-site interaction as the error term to evaluate treatment effects.

\subsection{Chemical analyses}

We analyzed samples of treated rice seed to determine the actual amount of caffeine applied. In Florida, we collected 20-g samples of rice treated with 1000, 1500, and $2500 \mathrm{ppm}$ caffeine immediately after treatment. In Louisiana, we collected $20 \mathrm{~g}$ samples of $10,000 \mathrm{ppm}$ caffeine-treated rice upon formulation of the treated rice, and 16, 24, 48 and $63 \mathrm{~h}$ post-application on study sites. Each sample was placed in an amber jar, labeled, frozen, and shipped with freezer packs overnight to the NWRC Analytical Chemistry Project in Fort Collins, Colorado where samples were kept at $-15^{\circ} \mathrm{C}$ until assayed in triplicate. A $0.5-\mathrm{g}$ portion of sample was weighed into a tared $50 \mathrm{~mL}$ Nalgene ${ }^{\circledR}$ screw top tube. The samples were extracted by the addition of $20 \mathrm{~mL}$ of methanol and vortex mixed followed by shaking on a mechanical shaker for $10 \mathrm{~min}$ and $10 \mathrm{~min}$ in an ultrasonic bath. Each sample was centrifuged for $2 \mathrm{~min}$, and the supernatant was decanted into a $50 \mathrm{~mL}$ volumetric flask. The extraction procedure was then repeated with 20 and $8 \mathrm{~mL}$ of methanol. After all of the extracts have been combined in the $50 \mathrm{~mL}$ volumetric flask the final volume is taken to $50 \mathrm{~mL}$ with methanol and vortex mixed. A 1-mL aliquot of each sample extract was combined with $1 \mathrm{~mL}$ of mobile and vortex mixed followed by filtration through a $0.45-\mu \mathrm{m}$ syringe filter into a vial and capped. All samples and standards were analyzed by high performance liquid chromatography (HPLC) with a Hewlett Packard $1090 \mathrm{M}$ equipped with a diode array UV-visible detector. Quality control (QC) samples were prepared at 0,5000 and $12,500 \mathrm{ppm}$ 
caffeine with homogenized untreated rice seed. The QC samples were prepared by dry spiking technical grade ( $>99 \%$ purity) caffeine onto 0.5 -g portions of homogenized untreated seed and vortex mixing for $30 \mathrm{~s}$.

\section{Results}

\subsection{Individual cage trials}

For female red-winged blackbirds, total consumption differed $\left(F_{3,16}=3.45, P=0.042\right)$ among test groups, with the $1000 \mathrm{ppm}$ group consuming the most rice seed $\left(\bar{x}=4.47 \mathrm{~g} \mathrm{bird}^{-1}, \mathrm{SE}=0.24\right)$ and the $1500 \mathrm{ppm}$ group the least $\left(\bar{x}=3.04 \mathrm{~g} \mathrm{bird}^{-1}, \mathrm{SE}=0.21\right)$. The interaction $\left(F_{21,112}=2.49, P=0.001\right)$ reflects that rice consumption by the $1500 \mathrm{ppm}$ treatment group declined $56 \%$ during the treatment period relative to the untreated group whereas the other test groups maintained or increased pretreatment levels of consumption (Fig. 1). One bird in the $2500 \mathrm{ppm}$ group persistently consumed treated rice which caused the group's mean consumption to be relatively high. Changes in body mass of test birds varied $\left(F_{3,16}=6.32, P=0.005\right)$ with treatment group. The control group gained an average of almost $2 \mathrm{~g} \mathrm{bird}^{-1} \quad(\mathrm{SE}=0.9)$ while the 2500-ppm treatment group lost an average of $2.5 \mathrm{~g} \mathrm{bird}{ }^{-1}(\mathrm{SE}=0.8$, Fig. 2). The individual in the 2500-ppm group that persistently consumed treated rice throughout the trial lost $11 \%$ of its initial body mass, by far the most of any bird.

Rice consumption varied $\left(F_{3,16}=7.47, P=0.002\right)$ among test groups of male brown-headed cowbirds, with the control group consuming the most

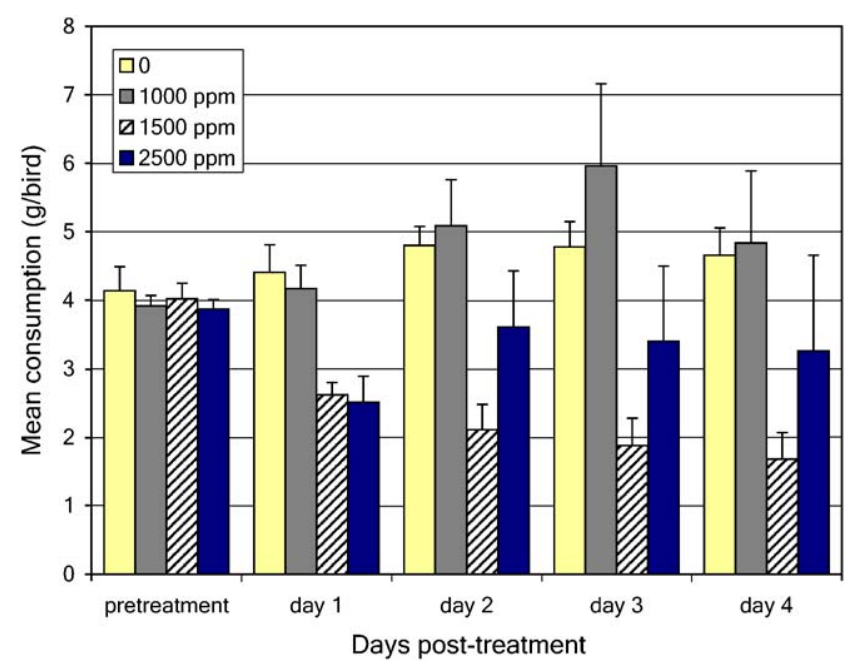

Fig. 1. Rice consumption by groups of individually caged female redwinged blackbirds exposed to untreated (pretreatment period) rice and caffeine-treated rice (treatment days 1-4). Each bird was given one cup of rice for $3 \mathrm{~h}$ daily. Pretreatment means are calculated for the 4-day pretreatment period. Capped vertical bars denote $1 \mathrm{SE}$.

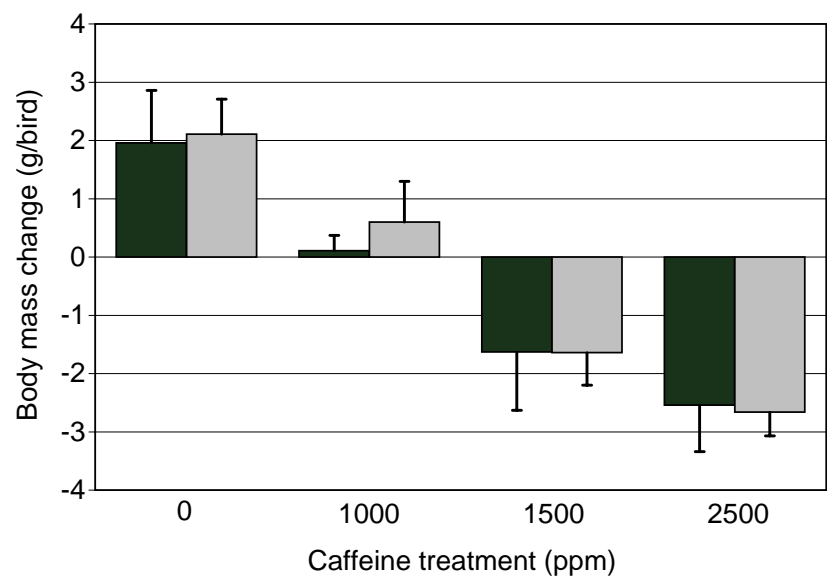

Fig. 2. Mean changes in body mass of female red-winged blackbirds (dark bars) and male brown-headed cowbirds (light bars) during a 10-

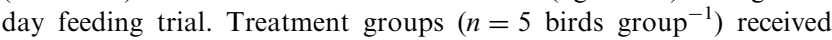
untreated rice for $3 \mathrm{~h}$ on each of the 4 pretreatment days, then after a 2-day break, birds received caffeine-treated rice for $3 \mathrm{~h}$ on each of the 4 treatment days. When not being tested birds were allowed unlimited access to standard maintenance diet. Capped vertical bars denote $1 \mathrm{SE}$.

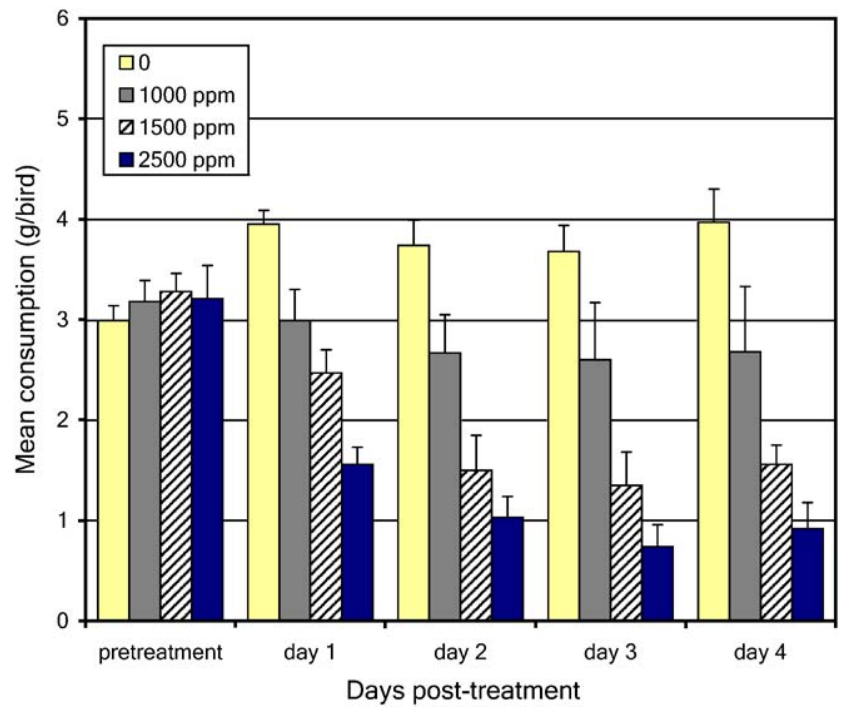

Fig. 3. Rice consumption by groups of individually caged male brownheaded cowbirds exposed to untreated (pretreatment period) rice and caffeine-treated rice (treatment days 1-4). Each bird was given one cup of rice for $3 \mathrm{~h}$ daily. Pretreatment means are calculated across the 4-day period. Capped vertical bars denote $1 \mathrm{SE}$.

$\left(\bar{x}=3.41 \mathrm{~g} \mathrm{bird}^{-1}, \mathrm{SE}=0.13\right)$ and the $2500-\mathrm{ppm}$ caffeine group eating the least $\left(\bar{x}=2.14 \mathrm{~g} \mathrm{bird}^{-1}\right.$, $\mathrm{SE}=0.20)$. Across all test groups, consumption varied with test day $\left(F_{7,112}=17.17, P<0.001\right)$. Greatest consumption occurred on treatment day $3\left(\bar{x}=3.48 \mathrm{~g} \mathrm{bird}^{-1}\right.$, $\mathrm{SE}=0.11)$, and consumption was least on day 7 $\left(\bar{x}=2.09 \mathrm{~g} \mathrm{bird}^{-1}, \mathrm{SE}=0.31\right)$. The interaction $\left(F_{21,112}=\right.$ $7.71, P<0.001)$ between test group and test day reflects that rice consumption by the 1500- and 2500-ppm treatment groups declined by $55 \%$ and $72 \%$, respectively, 
during the treatment period relative to the control group (Fig. 3). Throughout the study, changes in body mass of test birds varied $\left(F_{3,16}=13.61, P<0.001\right)$ with treatment group. The control group gained an average of $2.1 \mathrm{~g} \mathrm{bird}^{-1} \quad(\mathrm{SE}=0.6)$ while the 2500-ppm treatment group lost an average of $2.7 \mathrm{~g} \mathrm{bird}^{-1}$ $(\mathrm{SE}=0.4)$. The pattern of body mass change closely resembled that of the female red-winged blackbirds (Fig. 2).

We observed no obvious responses to caffeine-treated seed by the birds we video-taped. No bird displayed head-shaking or bill-wiping behavior which usually accompanies irritating or otherwise unpalatable food. Furthermore, no bird vomited or showed evidence of post-ingestional distress or discomfort.

\subsection{Flight pen trial}

After 3 days' exposure to mixed-species test groups of birds, an average of $463(\mathrm{SE}=6)$ rice seeds remained on sampling quadrats in treated test strips, compared to $276(\mathrm{SE}=44)$ seeds remaining in quadrats having untreated rice. This corresponds to estimated losses of $3.7 \% \quad(\mathrm{SE}=1.2)$ for caffeine-treated rice seed and $42.6 \% \quad(\mathrm{SE}=9.1) \quad$ for untreated seed $(t=4.04$, $P=0.027)$.

\subsection{Field evaluation}

Across the 5 study sites, blackbirds consumed more untreated rice than caffeine-treated rice $\left(F_{1,8}=9.5\right.$, $P=0.015)$. Of seeds placed on sample plots, an average of $92 \%$ of caffeine-treated rice remained uneaten on days 2 and 3 whereas $>80 \%$ of untreated rice was consumed (Fig. 4). The average abundance of blackbirds associated with caffeine-treated and untreated

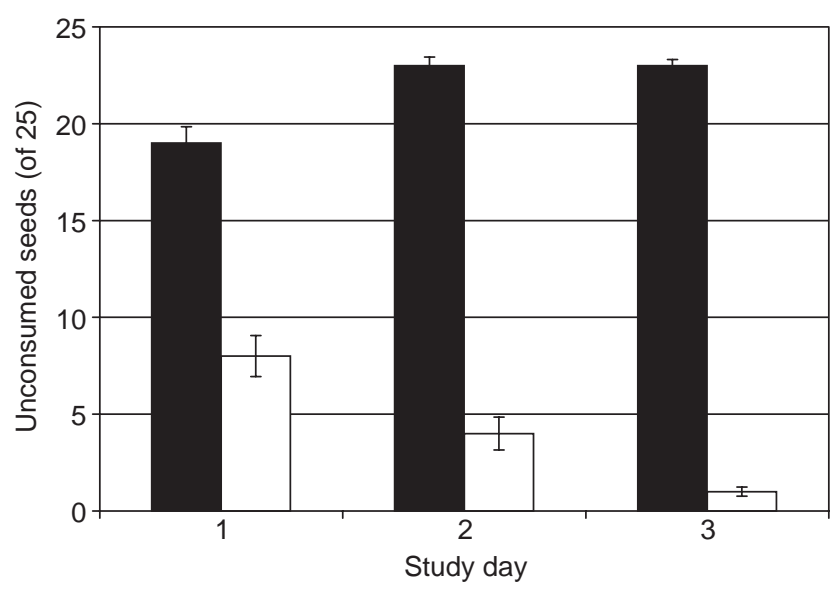

Fig. 4. Mean $( \pm S E)$ number of rice seeds remaining in sampling plots on lanes baited with 10,000-ppm caffeine-treated (dark bars) and untreated rice (light bars) in southwestern Louisiana ( $n=5$ study sites). Each day, each sampling plot initially held 25 rice seeds.

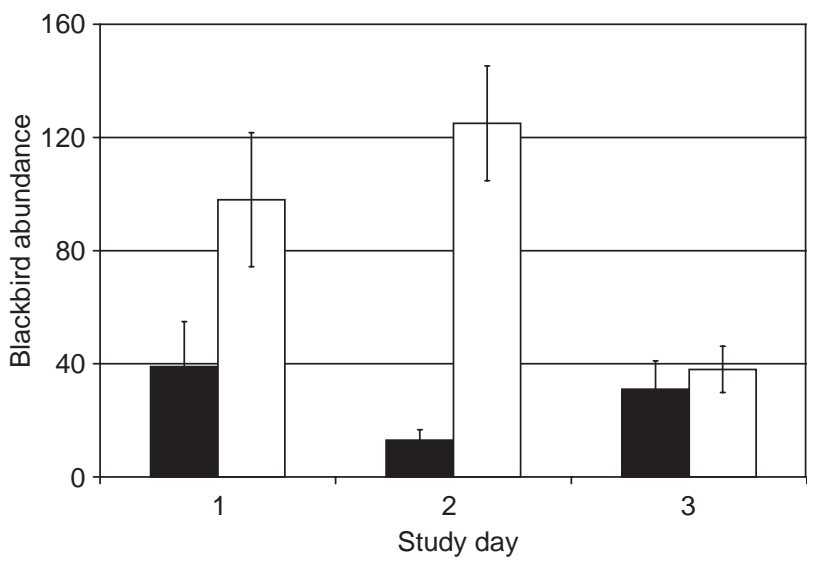

Fig. 5. Mean $( \pm S E)$ blackbird abundance on lanes baited with 10,000 ppm caffeine-treated (dark bars) and untreated rice (light bars) in southwestern Louisiana ( $n=5$ study sites).

lanes was 28 blackbirds $(\mathrm{SE}=6)$ and 87 blackbirds $(\mathrm{SE}=11)$, respectively $\left(F_{1,8}=3.8, P=0.087\right)$. By day 3 , total blackbird use of the study sites was reduced (Fig. 5).

\subsection{Chemical analyses}

The mean recovery of all fortified quality control samples assayed was $99.2 \pm 1.2 \%(n=20)$. A few QC samples were spiked with caffeine solutions in methanol. The methanol was evaporated and the samples were analyzed and no difference in recovery was observed from the dry spikes. The method limit of detection was determined to be $30 \mathrm{ppm}$ of caffeine based on a caffeine response equivalent to three times the baseline noise at the retention time of the analyte.

In cage trials, the target treatment rates were 1000 , 1500 and $2500 \mathrm{ppm}$. Actual measured caffeine treatment rates were $684 \mathrm{ppm}(\mathrm{SD}=4), 1090 \mathrm{ppm}(\mathrm{SD}=300)$, and $2060 \mathrm{ppm}(\mathrm{SD}=780)$, respectively. Although the nominal caffeine treatment rate for the field trial was $10,000 \mathrm{ppm}$, mean recovery from samples of treated rice prior to field application ranged from $7630 \mathrm{ppm}$ to $10,700 \mathrm{ppm}$ caffeine. We recovered $5210 \mathrm{ppm}$ (SD = $170), \quad 4270 \mathrm{ppm} \quad(\mathrm{SD}=160)$, and $4580 \mathrm{ppm} \quad(\mathrm{SD}=$ 180) caffeine from samples of treated rice that were collected from the field 16,24 and $48 \mathrm{~h}$ post-application, respectively. We detected no caffeine among rice samples collected $63 \mathrm{~h}$ post-application.

\section{Discussion}

The results of this study confirm and extend earlier findings of caffeine repellency to rice-eating blackbirds (Avery and Cummings, 2003). With the exception of one female red-winged blackbird in the 2500-ppm treatment 
group, reductions in consumption in 1-cup feeding trials with male and female blackbirds and male brownheaded cowbirds have been consistent. In flight pen and field trials, when mixed-species feeding flocks were exposed to caffeine-treated rice in the presence of alternate foods, rejection of caffeine-treated rice was enhanced. In fact, the field data suggest that birds quickly learned to avoid eating caffeine-treated rice, as the disparity in consumption between treated and untreated seed appeared to increase substantially from day 1 to subsequent days (see Fig. 4). Furthermore, differential use by blackbirds of untreated test sites relative to treated lanes increased from day 1 to day 2 (Fig. 5). Then by day 3 of the trial, total blackbird activity at test sites was reduced, presumably because birds chose to forage elsewhere rather than eat caffeinetreated seed after having exhausted the available supply of untreated rice seed.

While test birds in the cage trials exposed to caffeinetreated rice lost body mass, no mortality or permanent effects occurred. Free to choose other foods in field applications, birds will likely avoid caffeine-treated rice and suffer no ill effects. The amount of caffeine used in a rice field application will depend on the treatment rate and the seeding rate. In our field evaluation, we applied caffeine to rice seed at a rate of $10,000 \mathrm{ppm}$. If this treatment is applied to rice planted at a typical rate of $135 \mathrm{~kg} \mathrm{ha}^{-1}\left(120 \mathrm{lb} \mathrm{ac}^{-1}\right)$, then caffeine use will be $1350 \mathrm{~g} \mathrm{ha}^{-1}$. If the rice is used in a water-seeded operation, and if water is $10-\mathrm{cm}$ deep, and if all of the caffeine applied to the seed dissolves into the water, then the maximum caffeine concentration in the field water will be $1.350 \mathrm{ppm}$, or $1.35 \mathrm{mg} \mathrm{L}^{-1}$. This hypothetical worst-case concentration compares favorably to available aquatic toxicity data. For example, the $\mathrm{LC}_{50}$ for carp Leuciscus idus is reported as $87 \mathrm{mg} \mathrm{L}^{-1}$ and the $\mathrm{EC}_{50}$ for Daphnia magna is $182 \mathrm{mg} \mathrm{L}^{-1}$ (http://docs. appliedbiosystems.com/pebiodocs/00103271.pdf). Also, the $\mathrm{LC}_{50}$ for Xenops frog and fathead minnow Pimephales embryos are 190 and $720 \mathrm{mg} \mathrm{L}^{-1}$, respectively (DeYoung et al., 1996). The onset of teratogenic effects in Xenops and Pimephales occurred at caffeine concentrations $>30$ and $>20 \mathrm{mg} \mathrm{L}^{-1}$, respectively (DeYoung et al., 1996). Thus, the risk of aquatic toxicity effects from caffeine-treated rice seed appears low. Nevertheless, additional toxicity testing is needed, particularly to ensure that harvested crawfish populations in rice fields and adjacent ponds are not adversely affected.

Food-grade caffeine can be purchased in bulk which will make the cost of the proposed rice seed treatment affordable. The cost of bulk caffeine is presently $<\$ 3 \mathrm{~kg}^{-1}$ (Flavine North America, Inc., Closter, NJ). Thus, a $1 \%$ caffeine treatment would cost rice producers approximately $\$ 4 \mathrm{ha}^{-1}$, not an excessive expenditure for control of blackbird damage, provided that the treatment is at least partially effective (D. Hardee, Louisiana Rice Growers Association, pers. comm.).

One potential constraint to field application of caffeine as a bird repellent for rice and other crops is its formulation and use with conventional seed treatment and aerial application equipment. The solubility of caffeine at ambient temperature $\left(20-25^{\circ} \mathrm{C}\right)$ is low, and sprayers and seed-treatment equipment are easily clogged with undissolved particles of caffeine. The addition of sodium benzoate, a commonly used food preservative, greatly increases the solubility of caffeine at room temperature, and we are currently investigating its possible use as an adjuvant in caffeine spray formulations. An improved formulation must also extend the field life of caffeine treatment on rice seed. We detected no caffeine on rice that had been in the field $63 \mathrm{~h}$. This is inadequate because water-seeded rice is vulnerable to blackbird depredations for up to 2 weeks after planting. Greater adherence to the seed would also limit the amount of caffeine released into the general rice field environment and further reduce potential aquatic toxicity effects.

Although this study specifically addressed the issue of blackbird damage to newly seeded rice, our findings suggest that caffeine might also be used effectively to reduce bird damage to ripening rice. In addition to formulation issues previously noted, the major challenge to effective aerial applications to ripening rice is delivering sufficient amounts of caffeine to the panicles. Whether this will be feasible or not will be determined by research currently underway.

\section{Acknowledgements}

Funding was provided by the USDA National Wildlife Research Center, the Louisiana Rice Research Board, and the Louisiana State University Rice Research Station. C. Furcolow assisted with chemical analyses, K. Roca and E. Bruce maintained test birds in captivity, and D. LeBlanc and A. Wilson facilitated the field work. Research was conducted under study protocols QA-1037 and QA-1127 following procedures approved by the Animal Care and Use Committee of the USDA National Wildlife Research Center.

\section{References}

Avery, M.L., Cummings, J.L., 2003. Chemical repellents for reducing crop damage by blackbirds. In: Linz, G.M. (Ed.), Proceedings of Symposium on Management of North American Blackbirds, The Wildlife Society Eighth Annual Conference, Bismarck, ND, pp. 41-48.

Avery, M.L., Decker, D.G., Humphrey, J.S., Aronov, E., Linscombe, S.D., Way, M.O., 1995. Methyl anthranilate as a rice seed treatment to deter birds. J. Wildl. Manage. 59, 50-56. 
Avery, M.L., Humphrey, J.S., Primus, T.M., Decker, D.G., McGrane, A.P., 1998. Anthraquinone protects rice seed from birds. Crop Protection 17, 225-230.

Besser, J.F., 1985. A grower's guide to reducing bird damage to US agriculture crops. US Department of the Interior Denver Wildlife Research Center Bird Damage Research Report 340, 90pp.

Decker, D.G., Avery, M.L., Way, M.O., 1990. Reducing blackbird damage to newly planted rice with a nontoxic clay-based seed coating. Proc. Vertebr. Pest Conf. 14, 327-331.

DeYoung, D.J., Bantle, J.A., Hull, M.A., Burks, S.L., 1996. Differences in sensitivity to developmental toxicants as seen in Xenops and Pimephales embryos. Bull. Environ. Contam. Toxicol. 56, 143-150.

Hollingsworth, R.G., Armstrong, J.W., Campbell, E., 2002. Caffeine as a repellent for slugs and snails. Nature 417, 915-916.
Nathanson, J.A., 1984. Caffeine and related methylxanthines: possible naturally occurring pesticides. Science 226, 184-187.

SAS Institute, Inc., 1999. SAS/STAT User's Guide, Version 8. SAS Institute, Cary, North Carolina, USA.

Schafer, E.W., Bowles, W.A., Hurlbut, J., 1983. The acute oral toxicity, repellency, and hazard potential of 998 chemicals to one or more species of wild and domestic birds. Arch. Environm. Contam. Toxicol. 12, 355-382.

Weinberg, B.A., Bealer, B.K., 2001. The World of Caffeine. Routledge, New York 394pp.

Wilson, E.A., LeBoeuf, E.A., Weaver, K.M., LeBlanc, D.J., 1989. Delayed seeding for reducing blackbird damage to sprouting rice in southwestern Louisiana. Wildl. Soc. Bull. 17, 165-171.

Windholz, M. (Ed.), 1983, The Merck Index, 10th ed. Merck \& Co. Inc., Rahway, NJ. 